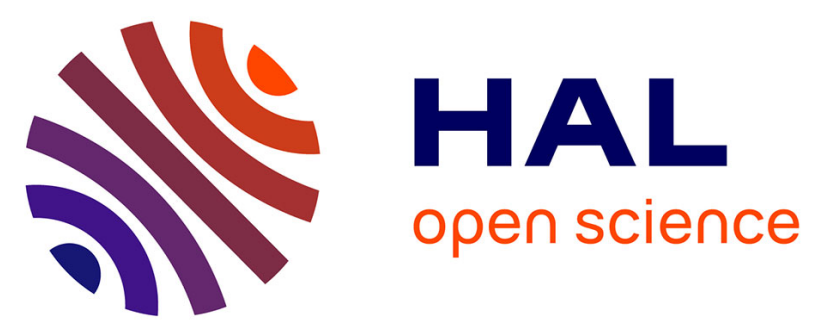

\title{
Synthesis, characterisation and antifungal activity of a series of Cobalt(II) and Nickel(II) complexes with ligands derived from reduced $\mathrm{N}$, N'-o-Phenylenebis(Salicylideneimine)
}

Sabrina Belaïd, Anne Landreau, Safia Djebbar, Ouassini Benali-Baïtich, Mustayeen A Khan, Gilles Bouet

\section{To cite this version:}

Sabrina Belaïd, Anne Landreau, Safia Djebbar, Ouassini Benali-Baïtich, Mustayeen A Khan, et al.. Synthesis, characterisation and antifungal activity of a series of Cobalt(II) and Nickel(II) complexes with ligands derived from reduced N, N'-o-Phenylenebis(Salicylideneimine). Transition Metal Chemistry, 2008, 33 (4), pp.511-516. 10.1007/s11243-008-9073-z . hal-03243913

\section{HAL Id: hal-03243913 \\ https://univ-angers.hal.science/hal-03243913}

Submitted on 3 Jun 2021

HAL is a multi-disciplinary open access archive for the deposit and dissemination of scientific research documents, whether they are published or not. The documents may come from teaching and research institutions in France or abroad, or from public or private research centers.
L'archive ouverte pluridisciplinaire HAL, est destinée au dépôt et à la diffusion de documents scientifiques de niveau recherche, publiés ou non, émanant des établissements d'enseignement et de recherche français ou étrangers, des laboratoires publics ou privés. 


\title{
Synthesis, characterisation and antifungal activity of a series of Cobalt(II) and Nickel(II) complexes with ligands derived from reduced $N, N^{\prime}$-o-Phenylenebis(Salicylideneimine)
}

\author{
Sabrina Belaïd · Anne Landreau • \\ Safia Djebbar · Ouassini Benali-Baïtich • \\ Mustayeen A. Khan · Gilles Bouet
}

Received: 21 December 2007/ Accepted: 8 February 2008/Published online: 27 February 2008

(C) Springer Science+Business Media B.V. 2008

\begin{abstract}
The synthesis and characterisation by elemental analysis, conductivity, FTIR, UV-Visible, ESR and magnetic measurements are described for a series of complexes of nickel(II) and cobalt(II) with three ligands $\left(\mathrm{H}_{2} \mathrm{~L}^{1-3}\right)$ derived from reduced $N, N^{\prime}$-o-Phenylenebis(salicylideneimine). The complexes formed are identified as neutral species, where the ligands are coordinated through $\mathrm{N}$ and $\mathrm{O}$ donor atoms. The formulae obtained for the complexes are: $\left[\mathrm{CoL}\left(\mathrm{H}_{2} \mathrm{O}\right)_{2}\right]$ with octahedral geometry and $[\mathrm{NiL}]$ with tetrahedral geometry. Their antifungal activity is evaluated towards human pathogenic fungi including yeasts of the Candida genus, some opportunistic moulds belonging to the Aspergillus, Scedosporium genus and some dermatophytes. The cobalt complexes show a significant growth inhibition of yeasts tested and also to fungi of the genus Scedosporium which is of interest because these fungi are usually poorly susceptible to current antifungal including Amphotericin B and Itraconazole, chosen as reference in this study. The activity data show that the metal complexes are more potent than the parent ligand.
\end{abstract}

S. Belaïd · S. Djebbar · O. Benali-Baïtich

Laboratoire d'Hydrométallurgie et Chimie Inorganique

Moléculaire, USTHB, BP.32 El Alia, 16111 Bab-Ezzouar,

Alger, Algerie

S. Belaïd · A. Landreau · M. A. Khan · G. Bouet $(\square)$

Laboratoire SONAS EA 921, Faculté de Pharmacie,

University of Angers, 16 Boulevard Daviers,

49045 Angers Cedex 01, France

e-mail: gilles.bouet@univ-angers.fr

\section{Introduction}

The Schiff bases have been subject of great of interest for a number of years because of their various chemical and structural characteristics, and also their proved applications as biologically active molecules [1]. Their complexes are known to be biologically important and act as models to understand the structure of biomolecules and metalloproteins. They have also a variety of applications, including biological, clinical, analytical and also industrial purposes [2].

With increasing incidence of deep mycosis in recent years [3], there were more and more studies for screening new and more effective antimicrobial broad-spectrum drugs with low toxicity. The interest in the study of Schiff bases and their complexes containing oxygen and nitrogen donor atoms arises from their significant antifungal activity [4-6]. Inhibiting properties toward tumour growth were recently demonstrated for some Schiff base complexes [7].

The imine bond in Schiff bases can be easily reduced to give amino derivatives. The comparison of the ligand coordinating properties of reduced Schiff bases with their Schiff base parents showed that the basicity of $\mathrm{N}$ atoms is enhanced and also a greater flexibility as consequence of the hydrogenation of the $\mathrm{C}=\mathrm{N}$ bond, leading to more stable complexes [8-11]. For these reasons, the reduced Schiff bases have gained particular attention [12,13].

We have previously reported [6] a synthesis and characterisation of manganese(II) and copper(II) complexes with reduced Schiff bases, and their antifungal activity towards some human pathogenic fungi. The manganese complexes showed a significant growth inhibition of the dermatophytes tested and the fungi of the genus Scedosporium. This is very interesting as these fungi are usually poorly susceptible to current antifungals. 
To pursue these studies, we have chosen cobalt(II) and nickel(II) complexes. We report here, their synthesis, characterisation by elemental analysis, conductimetry, FTIR, UV-Visible, ESR and magnetic measurements and the results of their antifungal activities towards human pathogenic fungi.

\section{Experimental}

\section{Reactants}

All reactants and solvents used were analytical grade. The ligands were synthesised as previously described [11]. Hexahydrated cobalt and nickel chloride were purchased from Merck (France) and used without further treatment.

\section{Measurements}

Elemental analyses were carried out by the service d'Analyse, ICSN-CNRS, Gif sur Yvette (France). Melting points were determined with a digital melting point apparatus using capillary technique. The molar conductance measurements were carried out at $25{ }^{\circ} \mathrm{C}$ using a Tacussel CD810 conductivity meter on $10^{-3} \mathrm{M}$ solutions in DMSO.

IR spectra were obtained using a Perkin Elmer FT-IR spectrometer Spectrum-one Model, between 400 and $4,000 \mathrm{~cm}^{-1}$ (KBr disks). Electronic spectra were recorded with a Shimadzu UV 1601 spectrophotometer in DMSO solutions. The ESR measurements were performed in solution and in solid state, at both room temperature and $113 \mathrm{~K}$, on a Bruker EMX spectrophotometer (Université du Maine, France) and theoretical spectra were calculated with the help of SimFonia Bruker software. This programme uses a set of perturbation theory algorithms to quickly explore the parameter spaces involved in powder and solution spectra.

The magnetic measurements were carried out using a SQUID magnetometer in the $200-300 \mathrm{~K}$ range with a 10,000 G applied field, diamagnetic corrections were estimated from Pascal's constants and magnetic data were corrected for diamagnetic contributions of the sample holder.

\section{Preparation of the complexes}

The complexes were prepared by refluxing for $4-5 \mathrm{~h}$, $1 \mathrm{mmol}$ of the hexahydrated metal chloride with $1 \mathrm{mmol}$ of the ligand in absolute EtOH. The complexes precipitated as powders which were removed by filtration, washed with water-ethanol mixture $(50 / 50, \mathrm{v} / \mathrm{v})$, and finally dried in vacuum.
Biological activity of complexes

\section{Microorganisms and culture conditions}

Antifungal activity was assayed on different human pathogenic fungi, including yeasts of the Candida genus (C. albicans ATCC 66396, C. glabrata LMA 90-1085, C. tropicalis LMA 91-4959 and C. parapsilopsis LMA 93-8558), some opportunistic moulds belonging to the Aspergillus (A. fumigatus CBS 11326, A. terreus LMA 40700121, and A. flavus LMA 40110521) or Scedosporium genus (S. apiospermum LMA 90-4595 and S. prolificans LMA 40409298), and some dermatophytes (Microsporum gypseum 50500961, Microsporum persicolor LMA 92-806, Trichophyton mentagrophytes LMA 90-406 and Trichophyton tonsurans LMA 50600608). Yeasts and moulds were cultivated at $37^{\circ} \mathrm{C}$ on yeast extract-peptone-dextrose agar (YPDA) containing $0.5 \mathrm{~g} / \mathrm{L}$ chloramphenicol for 2 or 3 days for yeasts and opportunistic moulds, respectively. As for the dermatophytes, they were cultivated at $25{ }^{\circ} \mathrm{C}$ during 7 days on YPDA plates containing chloramphenicol and supplemented with $0.5 \mathrm{~g} / \mathrm{L}$ cycloheximide (Sigma) to avoid contamination by susceptible moulds like the aspergilli. After incubation, the inoculum suspension was prepared for yeasts by suspending one colony in $10 \mathrm{~mL}$ of sterile distilled water. For filamentous fungi, the mycelium was recovered by scraping the agar plates with $10 \mathrm{~mL}$ of sterile distilled water. For the sporulating aspergilli, conidia were then harvested by filtration through $25-\mu \mathrm{m}$ pore size nylon Monyl membranes and finally, absorbance of the filtrate at $630 \mathrm{~nm}$ was adjusted spectrophotometry to 0.1 . As for Scedosporium spp. and the dermatophytes, fungal suspensions were homogenised with a ground-glass grinder and finally adjusted by spectrophotometry to an $A_{450}$ of 0.4 .

\section{Determination of antifungal activity}

Antifungal activity of the different compounds (ligands, metal salts and complexes) was evaluated using a disk diffusion method routinely used for yeasts [14], and adapted here for dermatophytes and opportunistic moulds. Briefly, compounds were dissolved in DMSO at a final concentration of $10 \mathrm{mg} / \mathrm{mL}$ and $25-\mu \mathrm{L}$ aliquots were applied on 12-mm diameter paper disks (rf 06234304, Prolabo 33173 Gradigan, France). After evaporating the solvent, disks were deposited in the centre of $90-\mathrm{mm}$ diameter Casitone agar plates previously flooded with $10 \mathrm{~mL}$ of spore or hyphal fragment suspensions. Negative control was performed using filter papers soaked with an equal volume of respective metal salts and drug-free solvent (DMSO), and positive controls were made with Neosensitabs tablets of Amphotericin B or Itraconazole (Rosco Diagnostic, Taastrup, Denmark). After incubation, 
diameter of the growth inhibition zones (mm) was measured around the paper disks or Neosensitabs tablets.

\section{Results and discussion}

The physical properties and analytical data of the complexes are summarised in Table 1. The nickel and cobalt complexes were obtained as powders and attempts to obtain single crystal suitable for X-ray determination were unsuccessful. They are insoluble in water, partially soluble in methanol and ethanol, totally soluble in DMF and DMSO.

The elemental analysis and all the physical measurements permit the suggestion of these empirical formula: $\left[\mathrm{CoL}\left(\mathrm{H}_{2} \mathrm{O}\right)_{2}\right]$ and [NiL]. The molar conductivities of the complexes in DMSO indicate that they are non-electrolyte species [15].

IR spectra

These ligands are expected to act as tetradentate ones through nitrogen and oxygen atoms, as confirmed by X-ray structures reported for similar ligands [16-18].

A study and a comparison of the IR spectra of our ligands and their cobalt(II) and nickel(II) complexes allow us to determine the coordination sites of the ligands. The IR data is presented in Table 2 .

The free ligands show an absorption band near $3,200 \mathrm{~cm}^{-1}$ assigned to $\mathrm{NH}$ stretching vibration. A strong band is observed in the $1,500-1,600 \mathrm{~cm}^{-1}$ region assigned to $\mathrm{NH}$ deformation and $\mathrm{C}=\mathrm{C}$ stretching vibration. The $\mathrm{C}-\mathrm{N}$ and $\mathrm{C}-\mathrm{O}$ stretching vibrations bands are observed at 1,250 and $1,150 \mathrm{~cm}^{-1}$, respectively, the vibration band of phenolic $\mathrm{OH}$ is observed at ca. $3,050 \mathrm{~cm}^{-1}$ [19].
The most important changes occurring after complexation are:

- The disappearance of the $v(\mathrm{OH})$ band, due to the deprotonation of the ligands, leading to neutral complexes as indicated by conductimetric measurements.

- The shift to lower or higher wavenumbers of $\mathrm{C}-\mathrm{O}$ and $\mathrm{C}-\mathrm{N}$ vibration bands because of the involvement of oxygen and nitrogen atoms in the coordination. This is confirmed by the appearance of new bands around 400 and $500 \mathrm{~cm}^{-1}$ assigned to $\mathrm{M}-\mathrm{O}$ and $\mathrm{M}-\mathrm{N}$ bonds after complexation [20].

Finally, a broad band is observed around $3,400 \mathrm{~cm}^{-1}$ in the spectra of the cobalt complexes, assigned to coordinated water molecules.

Electronic spectra and magnetic measurements

The free ligands exhibit two intense bands in the 40,000$30,000 \mathrm{~cm}^{-1}$ region due to $\pi \rightarrow \pi^{*}$ transitions, which remain unchanged in the spectra of the complexes.

The electronic data of $\mathrm{d}-\mathrm{d}$ transitions of the complexes are summarised in Table 2. The $\left[\mathrm{CoL}^{1}\left(\mathrm{H}_{2} \mathrm{O}\right)_{2}\right]$ complex exhibits a magnetic moment of 5.08 BM corresponding to high spin octahedral cobalt(II) species [21]. It is supported by its electronic spectra where we observe three absorption bands at 10,593, 14,641 and $21,505 \mathrm{~cm}^{-1}$ corresponding to: ${ }^{4} \mathrm{~T}_{1 \mathrm{~g}} \rightarrow{ }^{4} \mathrm{~T}_{2 \mathrm{~g}},{ }^{4} \mathrm{~T}_{1 \mathrm{~g}} \rightarrow{ }^{4} \mathrm{~A}_{2 \mathrm{~g}}$ and ${ }^{4} \mathrm{~T}_{1 \mathrm{~g}} \rightarrow{ }^{4} \mathrm{~T}_{1 \mathrm{~g}}$ transitions, respectively [21-23].

The magnetic moments of the complexes $\left[\mathrm{CoL}^{2}\left(\mathrm{H}_{2} \mathrm{O}\right)_{2}\right]$ and $\left[\mathrm{CoL}^{3}\left(\mathrm{H}_{2} \mathrm{O}\right)_{2}\right]$ are 1.76 and $1.82 \mathrm{BM}$, respectively. They are typical of low spin octahedral cobalt(II) species. Their electronic spectra exhibit two bands around: 10,000, and $20,000 \mathrm{~cm}^{-1}$, assigned to: ${ }^{2} \mathrm{E}_{\mathrm{g}} \rightarrow{ }^{2} \mathrm{~T}_{1 \mathrm{~g}},{ }^{2} \mathrm{~T}_{2} ;{ }^{2} \mathrm{E}_{\mathrm{g}} \rightarrow{ }^{2}$ $\mathrm{A}_{1 \mathrm{~g}}$ transitions, respectively $[21,24,25]$.

Table 1 Analytical data and magnetic moments of the complexes

\begin{tabular}{|c|c|c|c|c|c|c|c|}
\hline \multirow[t]{2}{*}{ Complexes } & \multirow[t]{2}{*}{ Colour } & \multicolumn{3}{|c|}{ Elemental analysis found (calcd.) (\%) } & \multirow[t]{2}{*}{ M.p. $\left({ }^{\circ} \mathrm{C}\right)$} & \multirow[t]{2}{*}{$\Lambda\left(\Omega^{-1} \mathrm{~cm}^{2} \mathrm{~mol}^{-1}\right)$} & \multirow[t]{2}{*}{$\mu_{\mathrm{eff}}(\mathrm{BM})$} \\
\hline & & $\mathrm{C}$ & $\mathrm{H}$ & $\mathrm{N}$ & & & \\
\hline \multirow[t]{2}{*}[\mathrm{CoL}^{1}(\mathrm{H}_{2}\mathrm{O})_{2}]{} & Dark green & $(58.4)$ & $(5.4)$ & $(6.5)$ & 205 & 32 & 5.08 \\
\hline & & 58.1 & 5.3 & 6.8 & & & \\
\hline \multirow[t]{2}{*}[\mathrm{CoL}^{2}(\mathrm{H}_{2}\mathrm{O})_{2}]{} & Brown & $(59.6)$ & (5.3) & $(7.0)$ & 277 & 11 & 1.76 \\
\hline & & 59.0 & 5.6 & 6.6 & & & \\
\hline \multirow[t]{2}{*}[\mathrm{CoL}^{3}(\mathrm{H}_{2}\mathrm{O})_{2}]{} & Brown & $(53.1)$ & $(4.9)$ & $(6.7)$ & 256 & 15 & 1.82 \\
\hline & & 53.6 & 4.7 & 6.3 & & & \\
\hline \multirow[t]{2}{*}[\mathrm{NiL}^{1}]{} & Orange & $(62.5)$ & $(5.0)$ & (7.3) & 242 & 18 & 2.32 \\
\hline & & 62.7 & 4.8 & 7.4 & & & \\
\hline \multirow[t]{2}{*}[\mathrm{NiL}^{2}]{} & Orange & $(64.3)$ & $(4.2)$ & (7.3) & 261 & 24 & 2.56 \\
\hline & & 64.9 & 4.8 & 7.4 & & & \\
\hline \multirow[t]{2}{*}[\mathrm{NiL}^{3}]{} & Orange & (55.1) & (5.0) & (6.7) & 257 & 21 & 2.39 \\
\hline & & 54.9 & 4.8 & 6.5 & & & \\
\hline
\end{tabular}


Table 2 Relevant IR data $\left(\mathrm{cm}^{-1}\right)$ and electronic spectral data of the ligands and the complexes

\begin{tabular}{|c|c|c|c|c|c|c|c|c|c|c|c|}
\hline Complexes & $v(\mathrm{OH})^{\mathrm{a}}$ & $v(\mathrm{OH})^{\mathrm{b}}$ & $v(\mathrm{NH})$ & $v(\mathrm{C}-\mathrm{O})$ & $v(\mathrm{C}-\mathrm{N})$ & $v(\mathrm{C}-\mathrm{O})$ & $v(\mathrm{M}-\mathrm{N})$ & $v(\mathrm{M}-\mathrm{O})$ & $v^{-}\left(\mathrm{cm}^{-1}\right)$ & $\varepsilon\left(\mathrm{L} \mathrm{mol}^{-1} \mathrm{~cm}^{-1}\right)$ & Electronic transitions \\
\hline $\mathrm{H}_{2} \mathrm{~L}^{1}$ & - & $3061_{\mathrm{m}}$ & $3298_{\mathrm{s}}$ & $1465_{\mathrm{s}}$ & $1229_{m}$ & $1106_{\mathrm{m}}$ & - & - & $\begin{array}{l}30120 \\
32573 \\
36363\end{array}$ & $\begin{array}{l}1750 \\
5400 \\
9850\end{array}$ & $\begin{array}{l}\pi \rightarrow \pi^{*} \\
\pi \rightarrow \pi^{*} \\
\pi \rightarrow \pi^{*}\end{array}$ \\
\hline $\mathrm{H}_{2} \mathrm{~L}^{2}$ & - & $3040_{\mathrm{m}}$ & $3288_{\mathrm{s}}$ & $1496_{s}$ & $1235_{\mathrm{m}}$ & $1105_{\mathrm{m}}$ & - & - & $\begin{array}{l}30030 \\
32362 \\
36630\end{array}$ & $\begin{array}{l}1800 \\
6200 \\
8750\end{array}$ & $\begin{array}{l}\pi \rightarrow \pi^{*} \\
\pi \rightarrow \pi^{*} \\
\pi \rightarrow \pi^{*}\end{array}$ \\
\hline $\mathrm{H}_{2} \mathrm{~L}^{3}$ & - & $3030_{\mathrm{m}}$ & $3314_{\mathrm{s}}$ & $1446_{s}$ & $1265_{\mathrm{m}}$ & $1100_{\mathrm{m}}$ & - & - & $\begin{array}{l}27247 \\
32362 \\
37037\end{array}$ & $\begin{array}{r}2200 \\
6000 \\
16500\end{array}$ & $\begin{array}{l}\pi \rightarrow \pi^{*} \\
\pi \rightarrow \pi^{*} \\
\pi \rightarrow \pi^{*}\end{array}$ \\
\hline$\left[\mathrm{CoL}^{1}\left(\mathrm{H}_{2} \mathrm{O}\right)_{2}\right]$ & $3380_{\mathrm{br}}$ & - & $3309_{\mathrm{m}}$ & $1447_{\mathrm{m}}$ & $1242_{\mathrm{m}}$ & $1156_{\mathrm{m}}$ & $\begin{array}{l}521_{\mathrm{w}} \\
475_{\mathrm{w}}\end{array}$ & $\begin{array}{l}418_{\mathrm{w}} \\
408_{\mathrm{w}}\end{array}$ & $\begin{array}{l}10593 \\
14641 \\
21505\end{array}$ & $\begin{array}{r}45 \\
344 \\
490\end{array}$ & $\begin{array}{l}{ }^{4} \mathrm{~T}_{1 \mathrm{~g}} \rightarrow{ }^{4} \mathrm{~T}_{2 \mathrm{~g}} \\
{ }^{4} \mathrm{~T}_{1 \mathrm{~g}} \rightarrow{ }^{4} \mathrm{~A}_{2 \mathrm{~g}} \\
{ }^{4} \mathrm{~T}_{1 \mathrm{~g}} \rightarrow{ }^{4} \mathrm{~T}_{1 \mathrm{~g}}\end{array}$ \\
\hline$\left[\mathrm{CoL}^{2}\left(\mathrm{H}_{2} \mathrm{O}\right)_{2}\right]$ & $3350_{\mathrm{br}}$ & - & $3215_{\mathrm{m}}$ & $1458_{\mathrm{m}}$ & $1267_{\mathrm{m}}$ & $1149_{\mathrm{m}}$ & $\begin{array}{l}500_{\mathrm{w}} \\
455_{\mathrm{w}}\end{array}$ & $\begin{array}{l}433_{w} \\
422_{w}\end{array}$ & $\begin{array}{l}10060 \\
21052\end{array}$ & $\begin{array}{r}18 \\
852\end{array}$ & $\begin{array}{l}{ }^{2} \mathrm{E}_{\mathrm{g}} \rightarrow{ }^{2} \mathrm{~T}_{1 \mathrm{~g}},{ }^{2} \mathrm{~T}_{2 \mathrm{~g}} \\
{ }^{2} \mathrm{E}_{\mathrm{g}} \rightarrow{ }^{2} \mathrm{~A}_{1 \mathrm{~g}}\end{array}$ \\
\hline$\left[\mathrm{CoL}^{3}\left(\mathrm{H}_{2} \mathrm{O}\right)_{2}\right]$ & $3375_{\mathrm{br}}$ & - & $3204_{m}$ & $1460_{\mathrm{m}}$ & $1250_{\mathrm{m}}$ & $1149_{\mathrm{m}}$ & $\begin{array}{l}530_{\mathrm{w}} \\
468_{\mathrm{w}}\end{array}$ & $\begin{array}{l}439_{w} \\
416_{w}\end{array}$ & $\begin{array}{l}10131 \\
21186\end{array}$ & $\begin{array}{r}19 \\
425\end{array}$ & $\begin{array}{l}{ }^{2} \mathrm{E}_{\mathrm{g}} \rightarrow{ }^{2} \mathrm{~T}_{1 \mathrm{~g}},{ }^{2} \mathrm{~T}_{2 \mathrm{~g}} \\
{ }^{2} \mathrm{E}_{\mathrm{g}} \rightarrow{ }^{2} \mathrm{~A}_{1 \mathrm{~g}}\end{array}$ \\
\hline$\left[\mathrm{NiL}^{1}\right]$ & - & - & $3223_{\mathrm{m}}$ & $1466_{\mathrm{m}}$ & $1264_{\mathrm{m}}$ & $1158_{\mathrm{m}}$ & $\begin{array}{l}585_{\mathrm{w}} \\
523_{\mathrm{w}}\end{array}$ & $\begin{array}{l}420_{w} \\
408_{w}\end{array}$ & $\begin{array}{l}15037 \\
17667 \\
20833\end{array}$ & $\begin{array}{l}157 \\
210 \\
446\end{array}$ & $\begin{array}{l}{ }^{3} \mathrm{~T}_{1} \rightarrow{ }^{3} \mathrm{~A}_{2} \\
\}^{3} \mathrm{~T}_{1}\left({ }^{3} \mathrm{~F}\right) \rightarrow{ }^{3} \mathrm{~T}_{1}\left({ }^{3} \mathrm{P}\right)\end{array}$ \\
\hline$\left[\mathrm{NiL}^{2}\right]$ & - & - & $3282_{\mathrm{m}}$ & $1484_{m}$ & $1268_{\mathrm{m}}$ & $1113_{\mathrm{m}}$ & $\begin{array}{l}545_{\mathrm{w}} \\
503_{\mathrm{w}}\end{array}$ & $\begin{array}{l}453_{\mathrm{w}} \\
413_{\mathrm{w}}\end{array}$ & $\begin{array}{l}15250 \\
17667 \\
21141\end{array}$ & $\begin{array}{r}84 \\
144 \\
766\end{array}$ & $\begin{array}{l}{ }^{3} \mathrm{~T}_{1} \rightarrow{ }^{3} \mathrm{~A}_{2} \\
\}^{3} \mathrm{~T}_{1}\left({ }^{3} \mathrm{~F}\right) \rightarrow{ }^{3} \mathrm{~T}_{1}\left({ }^{3} \mathrm{P}\right)\end{array}$ \\
\hline$\left[\mathrm{NiL}^{3}\right]$ & - & - & $3260_{\mathrm{m}}$ & $1448_{\mathrm{m}}$ & $1266_{\mathrm{m}}$ & $1116_{\mathrm{m}}$ & $\begin{array}{l}525_{\mathrm{w}} \\
492_{\mathrm{w}}\end{array}$ & $\begin{array}{l}450_{\mathrm{w}} \\
416_{\mathrm{w}}\end{array}$ & $\begin{array}{l}15400 \\
17420 \\
21052\end{array}$ & $\begin{array}{l}110 \\
209 \\
760\end{array}$ & $\begin{array}{l}{ }^{3} \mathrm{~T}_{1} \rightarrow{ }^{3} \mathrm{~A}_{2} \\
\}^{3} \mathrm{~T}_{1}\left({ }^{3} \mathrm{~F}\right) \rightarrow{ }^{3} \mathrm{~T}_{1}\left({ }^{3} \mathrm{P}\right)\end{array}$ \\
\hline
\end{tabular}

${ }^{a}$ Water molecules

${ }^{\mathrm{b}}$ Phenolic

br: broad; m: medium; s: strong; w: weak

All the nickel complexes were found to be paramagnetic species and show magnetic moments values in the 2.32$2.56 \mathrm{BM}$ range, which are consistent with tetrahedral geometry. The coordination symmetry is probably $\mathrm{C}_{2 \mathrm{v}}$ $[2,26]$. Their electronic spectra show three absorption bands at 15,000, 17,000 and 20,000 $\mathrm{cm}^{-1}$ [21]. The first can be assigned to ${ }^{3} \mathrm{~T}_{1} \rightarrow{ }^{3} \mathrm{~A}_{2}$ transition, those at 17,000 and $20,000 \mathrm{~cm}^{-1}$ can be attributed to transitions from ${ }^{3} \mathrm{~T}_{1}\left({ }^{3} \mathrm{~F}\right)$ to the terms arising by splitting of ${ }^{3} \mathrm{~T}_{1}\left({ }^{3} \mathrm{P}\right)$ term in a crystal field of lower symmetry [21].

\section{Electron spin resonance}

The low spin cobalt complexes: $\left[\mathrm{CoL}^{2}\left(\mathrm{H}_{2} \mathrm{O}\right)_{2}\right]$ and $\left[\mathrm{CoL}^{3}\left(\mathrm{H}_{2} \mathrm{O}\right)_{2}\right]$ exhibit in the solid state at room temperature isotropic spectra. Their $g_{\text {iso }}$ values are in the 2.003-2.008 range.

In DMSO solution and at $250 \mathrm{~K}$, these complexes were inactive. When decreasing the temperature to $113 \mathrm{~K}$

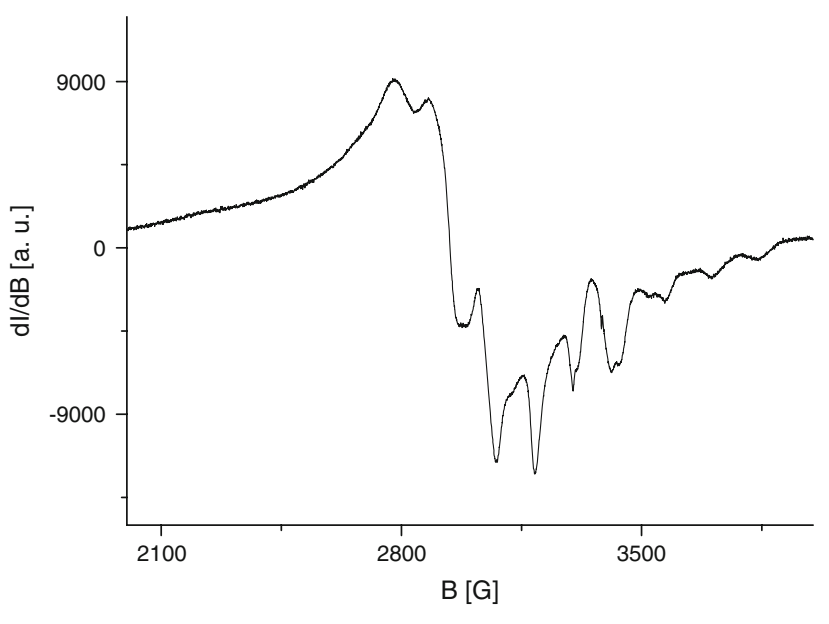

Fig. 1 ESR spectrum of $\left[\mathrm{CoL}^{3}\left(\mathrm{H}_{2} \mathrm{O}\right)_{2}\right]$ in DMSO solution at $113 \mathrm{~K}$

(vitreous state), hyperfine structure appears (Fig. 1) with eight hyperfine lines assigned to an interaction of an unpaired electron with ${ }^{59} \mathrm{Co}$ nucleus $(I=7 / 2)$. 
The parameters obtained by simulation are:

$$
\begin{aligned}
\text { For }\left[\mathrm{CoL}^{2}\left(\mathrm{H}_{2} \mathrm{O}\right)_{2}\right]: A_{x} & =113 \mathrm{G}, A_{y}=70 \mathrm{G}, A_{z}=150 \mathrm{G}, \\
g_{\mathrm{x}} & =2.28, g_{\mathrm{y}}=2.28, g_{\mathrm{z}}=2.05 . \\
\text { For }\left[\mathrm{CoL}^{3}\left(\mathrm{H}_{2} \mathrm{O}\right)_{2}\right]: A_{x} & =120 \mathrm{G}, A_{y}=40 \mathrm{G}, A_{z}=140 \mathrm{G}, \\
g_{x} & =2.28, g_{y}=2.20, g_{z}=2.02 .
\end{aligned}
$$

These values indicate the absence of axial symmetry and suggest that the water molecules are in cis position.

The high spin $\left[\mathrm{CoL}^{1}\left(\mathrm{H}_{2} \mathrm{O}\right)_{2}\right]$ complex was inactive in both solid state and solution. This behaviour could be attributable to the very short spin-lattice relaxation time of the $\mathrm{Co}$ (II) ions in octahedral field, as previously reported for similar complexes [27, 28].

\section{Complex structures}

On the basis of these results, it appears that the ligands are coordinated in a deprotonated form, through oxygen and nitrogen atoms leading to neutral complexes. The cobalt complexes are found to be octahedral with two coordinated water molecules probably in cis position. The elemental analysis indicates that the nickel complexes are tetracoordinated, their magnetic measurements suggest a tetrahedral geometry around nickel(II) ion. The proposed structures are given in Fig. 2.

\section{Antifungal activity}

The antifungal activity of the ligands and their complexes were tested in vitro against human pathogenic fungi, their activity was compared with those found for Amphotericin $\mathrm{B}$ and Itraconazole. The results are presented in Table 3.

As expected, no growth inhibition was observed for DMSO and metal salts. Amphotericin B and Itraconazole exhibited diameters ranging from 11 and $30 \mathrm{~mm}$ to 18 and $40 \mathrm{~mm}$ depending on the species, except for $S$. prolificans LMA 40409298 which was totally resistant to both drugs. In addition, Itraconazole was ineffective against $A$. fumigatus and $A$. terreus.

The results obtained as shown in Table 3 , indicate that the cobalt complexes exhibited noticeable antifungal susceptibilities against all the tested moulds, especially $C$. parapsilopsis. On the opposite side, the nickel complexes have only a weak activity against $C$. tropicalis (ranging from 14 to $24 \mathrm{~mm}$ ) and were quite inefficient against the others strains (data not shown).

The cobalt complexes showed a marked activity against yeasts and Aspergillus spp. with the largest effects attributed to the $\left[\mathrm{CoL}^{3}\left(\mathrm{H}_{2} \mathrm{O}\right)_{2}\right]$ complex. In this context because of their lack of activity, the corresponding ligands are not involved in the antifungal activity, suggesting that complexation with cobalt is totally implicated in the activity.
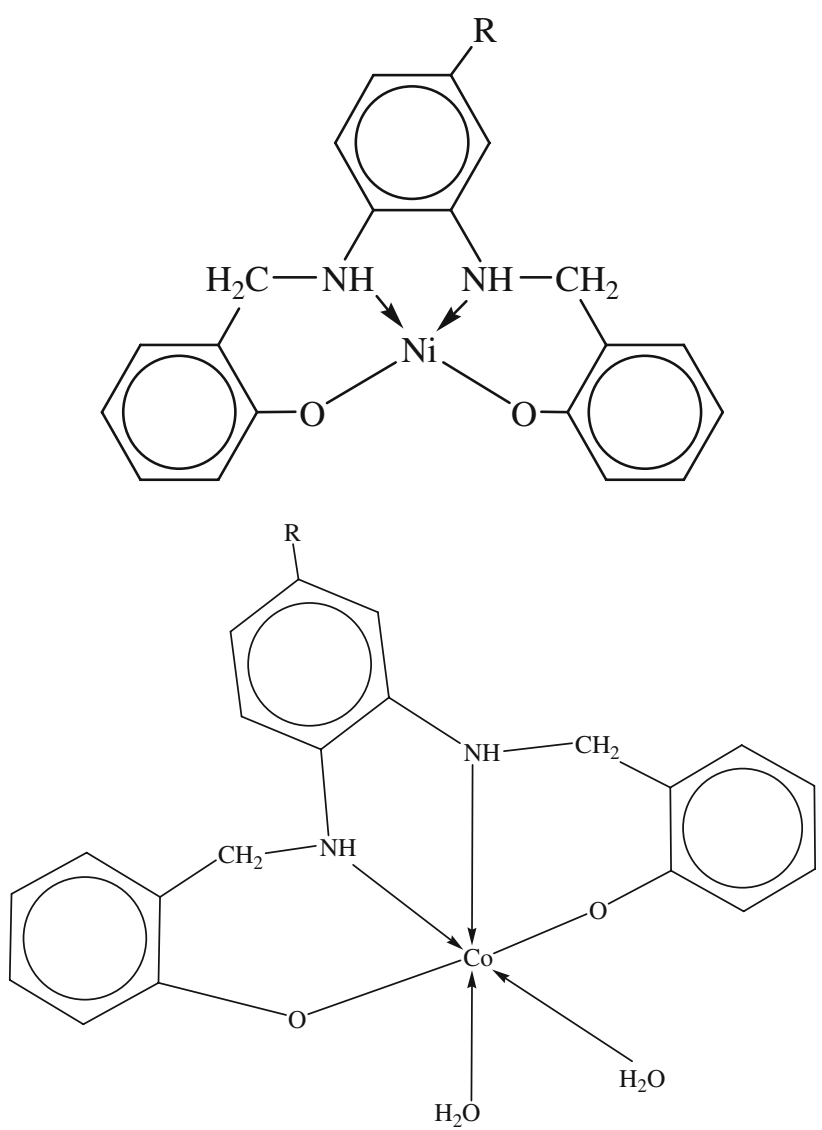

Fig. 2 Proposed structures for the complexes, $\mathrm{R}=\mathrm{H}$ : $\mathrm{H}_{2} \mathrm{~L}^{1}$, $\mathrm{R}=\mathrm{CH}_{3}: \mathrm{H}_{2} \mathrm{~L}^{2}, \mathrm{R}=\mathrm{Cl}: \mathrm{H}_{2} \mathrm{~L}^{3}$

Strikingly, no growth inhibition was observed for the dermatophytes tested, while our previously reported manganese complexes with the same ligands were active [6]. This observation brings up the hypothesis of a specificity of action of these molecules on yeasts and Aspergillus spp. on the one hand and dermatophytes on the other.

Additionally, the cobalt complexes showed a good activity on the two Scedosporium species i.e. S. apiospermum which ranks the second among the filamentous fungi colonising the airways of patients with cystic fibrosis [29] and $S$. prolificans causing severe disseminated infections in leukemic patients [30].

Here, the ligands seem to be involved in these results as suggested by their growth inhibition found versus the same strains. However, their activity was always less pronounced than for the complexes, indicating that complexation with cobalt enhances the antifungal activity of the ligands. This can be explained by chelation theory: chelation reduces the polarity of metal ion mainly because of partial sharing of its positive charge with the donor groups. Also, chelation increases the lipophilic nature of the metal ion which subsequently favours its permeation through the lipid layer of the cell membrane $[31,32]$. These last results are quite 
Table 3 Antifungal activities of ligands and complexes against pathogenic fungal strains, results correspond to the diameter of the inhibition zone $(\mathrm{mm})$

\begin{tabular}{|c|c|c|c|c|c|c|c|c|}
\hline & $\mathrm{H}_{2} \mathrm{~L}^{1}$ & $\mathrm{H}_{2} \mathrm{~L}^{2}$ & $\mathrm{H}_{2} \mathrm{~L}^{3}$ & {$\left[\mathrm{CoL}^{1}\left(\mathrm{H}_{2} \mathrm{O}\right)_{2}\right]$} & {$\left[\mathrm{CoL}^{2}\left(\mathrm{H}_{2} \mathrm{O}\right)_{2}\right]$} & {$\left[\mathrm{CoL}^{3}\left(\mathrm{H}_{2} \mathrm{O}\right)_{2}\right]$} & Amphotericine B & Itraconazole \\
\hline A. flavus & 0 & 0 & 0 & 14 & 0 & 16 & 14 & 18 \\
\hline A. fumigatus & 0 & 0 & 0 & 18 & 14 & 16 & 30 & 0 \\
\hline A. terreus & 0 & 0 & 0 & 13 & 0 & 20 & 11 & 0 \\
\hline C. albicans & 0 & 0 & 0 & 23 & 14 & 22 & 30 & 22 \\
\hline C. glabrata & 0 & 14 & 0 & 25 & 15 & 27 & 25 & 20 \\
\hline C. parapsilopsis & 0 & 0 & 0 & 36 & 28 & 33 & 25 & 35 \\
\hline C. tropicalis & 0 & 16 & 13 & 23 & 18 & 17 & 15 & 27 \\
\hline M. canis & 0 & 0 & 14 & 0 & 0 & 18 & 25 & 40 \\
\hline M. gypseum & 0 & 18 & 15 & 0 & 0 & 0 & 25 & 25 \\
\hline M. persicolor & 20 & 18 & 15 & 0 & 0 & 16 & 20 & 30 \\
\hline S. apiospermum & 23 & 22 & 18 & 30 & 16 & 35 & 14 & 20 \\
\hline S. prolificans & 22 & 20 & 14 & 38 & 23 & 27 & 0 & 0 \\
\hline T. mentagrophytes & 0 & 15 & 16 & 0 & 0 & 35 & 24 & 30 \\
\hline T. tonsurans & 0 & 20 & 16 & 0 & 0 & 13 & 25 & 25 \\
\hline
\end{tabular}

interesting because these fungi are usually poorly susceptible to current antifungals including Amphotericin B and Itraconazole chosen as a reference in this study.

\section{References}

1. Yamada S (1999) Coord Chem Rev 192:537

2. Jeewoth T, Bhowon MG, Wah HLK (1999) Transition Met Chem $24: 445$

3. Ostrosky-Zeichner L, Rex JH, Pappas PG, Hamill RJ, Larsen RA, Horowitz HW, Powderly WG, Hyslop N, Kauffman CA, Mangino JE, Lee J (2003) Antimicrob Agents Chemother 47:3149

4. Lv J, Liu T, Cai S, Wang X, Liu L, Wang Y (2006) J Inorg Biochem 100:1888

5. DelCampo R, Criado JJ, Garcia E, Hermosa MR, Jimenez-Sanchez A, Manzano JL, Monte E, Rodriguez-Fernandez E, Sanz F (2002) J Inorg Biochem 89:74

6. Belaid S, Landreau A, Djebbar S, Benali-Baitich O, Bouet G, Bouchara JP (2008) J Inorg Biochem 102:63

7. Gust R, Ott I, Posselt D, Sommer K (2004) J Med Chem 47:5837

8. Bottcher A, Elias H, Jager EG, Langlelderova H, Mazur M, Muller L, Paulus H, Pelikan P, Rudolph M, Valko M (1993) Inorg Chem 32:4131

9. Klement R, Stock F, Elias H, Paulus H, Pelikan P, Valko M, Mazur M (1999) Polyhedron 18:3617

10. Koh LL, Ranford JO, Robinson WT, Svensson JO, Tau ALC, Wu D (1996) Inorg Chem 35:6466

11. Belaid S, Djebbar S, Benali-Baitich O, Khan M, Bouet G (2007) CR Chim 10:568

12. Bernardo PD, Zanonato PL, Tamburini S, Tomasin P, Vigato PA (2006) Dalton Trans 4711

13. Groysman S, Sergeeva E, Goldberg I, Kol M (2005) Eur J Inorg Chem 2480
14. Barry AL, Brown SD (1996) J Clin Microbiol 2154

15. Geary JW (1971) Coord Chem Rev 7:81

16. Taylor MK, Reglinski J, Wallace D (2004) Polyhedron 23:3201

17. Atwood DA, Remington MP, Rutherford D (1996) Organometallics 15:4763

18. Atwood DA, Jeigier JA, Lindhom NF, Martin KJ, Rutherford D (1996) J Coord Chem 38:305

19. Bellamy LJ (1964) The infrared spectra of complex molecules. Wiley, New York

20. Nakamoto K (1997) Infrared and Raman spectra of inorganic and coordination compounds. Wiley, New York

21. Lever ABP (1997) Inorganic electronic spectroscopy. Elsevier, Amsterdam

22. Symons MCR, Taiwo T, Sargeson AM, Ali MM, Tabl AS (1996) Inorg Chim Acta 241:5

23. Djebbar-Sid S, Benali-Baitich O, Deloume JP (2001) J Mol Struct 569:121

24. Wayland BB, Abd-Elmageed ME, Mehne LF (1975) Inorg Chem 14:1456

25. Chikate RC, Padhye SB (2005) Polyhedron 24:1689

26. Gup R, Kirkan B (2005) Spectrochim Acta A 62:1188

27. March R, Clegg W, Coxall RA, Curcurull-Sanchez L, Lezama L, Rojo T, Gonzalez-Duarte P (2003) Inorg Chim Acta 353:129

28. Venter M, Haiduc I, David L, Cozar O (1997) J Mol Struct 408/ 409:483

29. Guarro J, Kantarcioglu AS, Horre R, Rodriguez-Tudela JL, Estrella MC, Berenguer J, Hoog GSD (2006) Med Mycol 44:295

30. Panackal AA, Marr KA (2004) Semin Respir Crit Care Med 25:171

31. Chaudhaery A, Singh RV (2003) Phosphorus Sulfur Silicon Relat Elem 178:603

32. Fahmi N, Gupta IJ, Singh RV (1998) Phosphorus Sulfur Silicon Relat Elem 132:1 